\title{
Effects of ENSO on Temperature, Precipitation, and Potential Evapotranspiration of North India's Monsoon: An Analysis of Trend and Entropy
}

\author{
Kazi Ali Tamaddun ${ }^{1}$, Ajay Kalra ${ }^{2}\left(\right.$, , Miguel Bernardez ${ }^{3}$ and Sajjad Ahmad ${ }^{1, *(1)}$ \\ 1 Department of Civil and Environmental Engineering and Construction, University of Nevada, \\ 4505 S. Maryland Parkway, Las Vegas, NV 89154-4015, USA; tamaddun@unlv.nevada.edu \\ 2 Department of Civil and Environmental Engineering, Southern Illinois University, 1230 Lincoln Drive, \\ Carbondale, IL 62901-6603, USA; kalraa@siu.edu \\ 3 Atmospheric and Oceanic Studies, University of Wisconsin-Madison, Madison, WI 53706, USA; \\ mbernard@nmt.edu \\ * Correspondence: sajjad.ahmad@unlv.edu; Tel.: +1-702-895-5456
}

Received: 17 December 2018; Accepted: 18 January 2019; Published: 23 January 2019

\begin{abstract}
The influence of El Niño Southern Oscillation (ENSO) on the north Indian temperature, precipitation, and potential evapotranspiration (PET) change patterns were evaluated during the monsoon season across the last century. Trends and shifts in 146 districts were assessed using nonparametric statistical tests. To quantify their temporal variation, the concept of apportionment entropy was applied to both the annual and seasonal scales. Results suggest that the El Niño years played a greater role in causing hydro-climatological changes compared to the La Niña or neutral years. El Niño was more influential in causing shifts compared to trends. For certain districts, a phase change in ENSO reversed the trend/shift direction. The century-wide analysis suggested that the vast majority of the districts experienced significant decreasing trends/shifts in temperature and PET. However, precipitation experienced both increasing and decreasing trends/shifts based on the location of the districts. Entropy results suggested a lower apportionment of precipitation compared to the other variables, indicating an intermittent deviation of precipitation pattern from the generic trend. The findings may help understand the effects of ENSO on the hydro-climatological variables during the monsoon season. Practitioners may find the results useful as monsoon is the most important season for India causing climate extremes.
\end{abstract}

Keywords: Indian monsoon; ENSO; North Indian climate; trend; shift; entropy; Indian climate extremes

\section{Introduction}

Studies on extreme climate events, i.e., droughts and floods, across the world, have found that such extremes are likely to be associated with the anomalies in zonal sea surface temperature (SST) fluctuations observed in the oceans. In turn, these fluctuations cause severe changes in the temperature and precipitation patterns, global and regional atmospheric pressure systems, formation of surface winds, and moisture sources and evaporative demands [1,2]. Studies also suggest that these extremes are likely being aggravated by global warming [3,4]. The recent California drought has been of great interest to many climate researchers, e.g., [5,6]. One study [7] identified major atmospheric circulation patterns affecting precipitation in California. However, the authors indicated that the contributions from the various components of the hydrologic cycle are yet to be properly understood. As a result, besides analyzing SST anomalies and precipitation patterns, recent studies have incorporated hydro-climatological variables like moisture sources, evaporative demand, and temperature in order to understand these climate extremes more thoroughly [7-9]. In addition, various 
combinations of these variables have been found to show significantly different and sometimes inverse correlations with certain climate extremes. A few cases-for example, lower moisture with higher temperature-were found to affect the extremes even more severely [8].

Several studies have presented ample evidence to support that climate change has immensely intensified the hydrologic cycle [10,11]. This intensification has raised questions [12-14] such as: What is the distribution of this intensification across the different components of the water cycle? How do changes in the amount of precipitation affect other components? And, what are the consequences of these changes in climate patterns? Some researchers have suggested that increased (decreased) precipitation can cause increased (decreased) vegetation, which in turn may cause an increase (decrease) in evapotranspiration [15-17]. Other studies have suggested that increased evapotranspiration resulting from increased vegetation may potentially affect the $\mathrm{CO}_{2}$ concentration, which in turn can act as a cooling mechanism to reduce the temperature [18-20]. These studies have shown how the dynamics among hydro-climatological variables might bring about a change in the long-term patterns and have reinforced the need for multi-variable analyses to predict and confront climate extremes.

Out of the many different regions of India, the northern region, referred to as North India in the following sections, is currently of particular interest to many climate researchers [21-23]. North India is situated in the Earth's northern temperate zone [24] and has experienced major climate diversity over the years [25-27]. Temperatures in North India have been recorded as varying over a wide range, from below freezing temperatures in some states to over $50{ }^{\circ} \mathrm{C}$ in the deserts [28-30]. Rainfall and snow in North India result from two major weather patterns, i.e., the western disturbances and the Indian monsoon. The western disturbances, originating from the Atlantic Ocean as well as the Caspian and the Mediterranean Seas, are called extratropical weather phenomena; they carry moisture towards the east over North India [31-33]. On the other hand, the monsoon, a large-scale circulation pattern lasting from June through September each year, carries moisture of the humid southwest summer wind from the Indian Ocean towards the north and provides the vast majority of the annual rainfall to the entire Indian subcontinent. As a result, understanding the behavior of the monsoon has been of major interest to climatologists for many years.

The India Meteorological Department (IMD) has observed and recorded monsoon patterns for several decades and has developed multiple stochastic models to forecast the initiation, recession, and strength of the Indian summer monsoon rainfall (ISMR). Out of the many different factors affecting ISMR, the El Niño Southern Oscillation (ENSO) has been considered to be one of the most significant large-scale forces that influences the behavior of ISMR [34,35]. ENSO is a natural cycle caused by the SST fluctuations originating from the strengthening and weakening of the trade winds [36]. It is observed in the tropical Pacific and affects the surrounding oceanic-atmospheric systems [37-39]. ENSO consists of two phases, namely, El Niño, which is the warmer (positive) phase, and La Niña, which is the cooler (negative) phase [40]. Each phase can last from a few months to a year, and they occur every two to seven years. From 1950 to 2012, ISMR was found to be above average or around average in almost all the La Niña years. Contrarily, five of the most prominent droughts in India during that period coincided with the El Niño years [41]. A monsoon followed by El Niño does not necessarily result in poor rainfall all the time; however, as studies suggest, there might be other climate and weather factors, e.g., the extent of Himalayan/Eurasian snow, that influence the circulation of the monsoon [35]. Studies have also suggested that other factors complementary to ENSO may affect ISMR, e.g., the Indian Ocean dipole (IOD), complex coupling and dynamics of multiple variables, and variations in heat flux over different land masses [42-44].

The tropical Indian Ocean experiences a basin-wide change after an ENSO event. In the north equatorial Indian Ocean, this change starts in late winter (early spring) and continues until summer. The prolonged influence of ENSO continues into the following seasons, and eventually causes climate anomalies in Southeast Asia, especially during summer [45,46]. Analyzing the phase relationships between ENSO and ISMR, one study [47] found significant correlations across several timescales, with stronger coherence during intervals of higher variance. Another study [43] found that ENSO, along 
with IOD, affected the rainfall amount immensely from 1958 to 1997. Other researchers observed that IOD could reduce the effect of ENSO on ISMR based on the different phased relationships $[48,49]$. This explains why all the years associated with El Niño did not cause a drought in India. A further study [50] found a strong correlation between inter-decadal ISMR and ENSO variations. In addition, this study explained the possible reasons for major regional and equatorial circulation patterns, e.g., Hadley circulation and Walker circulation, and how their anomalies caused these variations.

A study [41] suggested that the SST anomalies in the central (eastern) equatorial Pacific strengthen (weaken) the likelihood of droughts during the monsoon. Other studies observed multi-scale, e.g., interannual, quasi-decadal, and decadal variations, relationships among ISMR, Indian Ocean oscillations, and the ENSO phases [51-53]. Besides monsoon rain, temperature variations of the tropical Indian Ocean, along with the prolonged effects of ENSO and the associated heat flux over India, were studied by the authors of [44,46]. One study [45] concluded that El Niño not only affects SST fluctuations of the Indian Ocean but also plays an important role in the summer climate variability across the Indo-Western Pacific basins. A study [54] found that El Niño alters the cloud cover and evaporation configuration of atmospheric circulations, which in turn affect the heat flux of the surrounding basins. Another study [55] observed major shifts in the intensity and initiation of monsoon after the 1970s, which likely were affected by anomalies in global temperature and precipitation.

Analyzing anomalies in pressure, temperature, wind, and cloud cover over the Indian Ocean in the different phases of ENSO during monsoon, [51] emphasized that multi-variable analyses need to be conducted across various temporal scales, e.g., annual and seasonal, for a better understanding of the physical relationships and correlation patterns. Some combinations of the interconnected hydro-climatological variables and their extremes, such as lower precipitation levels with higher temperatures, have the potential to cause severe adversity in the hydro-ecological as well as the socio-economic systems, even though the individual variables may not indicate extreme conditions [56]. Considering the advantages of multi-variable analyses as a major motivation, the current study focused on understanding the influence of ENSO on the spatiotemporal change patterns of three hydro-climatological variables-temperature, precipitation, and potential evapotranspiration (PET) - during the monsoon season across North India. In addition, this study determined the all-year (century-wide) trend and shift patterns of the selected variables from 1901 to 2002. The Mann-Kendall test $[57,58]$ and Pettitt's test [59] - both nonparametric in nature - were used to detect the presence of trends and shifts, respectively. To evaluate the distribution (apportionment) of the temporal variability of the historical changes on an annual and seasonal scale, the concept of entropy was applied, which quantitatively measured the dispersion, disorder, and variability in the long-term trends [60]. Moreover, the study provided an extensive literature review of the relevant studies highlighting the relationships between monsoonal change patterns and the ENSO phases, and applied the multi-variable analyses approach to provide insights that may explain some of the research questions discussed earlier. The results obtained may help practitioners to prepare for flood and drought risks as a response to the changes in ENSO phases. The major contributions of the study are:

- Evaluation of the long-term trend and shift patterns of temperature, precipitation, and PET across North India in various ENSO phases using nonparametric statistical tests;

- Determination of the spatiotemporal relationships between the selected variables during the monsoon and at each of the monsoonal months over century-wide data;

- Comparison between the major shift points during monsoon and the phases of ENSO, which might have resulted in extreme climate events, throughout the study period;

- Analyses of apportionment entropy to quantify how the detected variations were distributed temporally over the years (annually) and during the months (seasonally) of monsoon along the study area. 


\section{Study Area and Data}

According to the Geological Survey of India [61], eight states, namely, Chandigarh, Delhi, Haryana, Himachal Pradesh, Jammu and Kashmir, Punjab, Uttarkhand, and Uttar Pradesh, officially form the northern region of India. These eight states consist of 147 districts. The supplementary material (Table S1) contains the names of the individual districts in each of the states. As reported by the IMD, the monsoon or the rainy season lasts from June to September. Temperature, precipitation, and PET data were obtained from 1901 to 2002 on a monthly mean basis for 146 districts, as data for one of the districts were unavailable (Figure 1). The data were accessed through the online database of the India Water Portal (IWP) [62]. The IWP database contains data in downloadable "comma-separated values" format (more commonly known as the csv format) after initial error correction. Then, the downloaded data were standardized by subtracting the mean and dividing by the standard deviation. Moreover, the methods used in the study (described in the next section) are resilient against outliers and missing data points, which makes them appropriate for the types of analyses adopted in the study. The trend/shift patterns of the selected variables were evaluated during the monsoon in four different combinations of the ENSO phases, namely, (1) the El Niño years, (2) the La Niña years, (3) the non-El Niño years (either the La Niña or neutral years), (4) and the non-La Niña years (either the El Niño or neutral years). The ENSO (Niño 3.4) indices used in this study (Figure 2) were accessed through the online database of the United States National Oceanic and Atmospheric Administration [63]. During the study period of 102 years, there were 37 instances that were found to be neutral years, 32 instances were found to be El Nino years, and 33 instances were found to be La Nina years. Hence, a total of 70 instances were non-El Niño years, while a total of 69 instances were non-La Niña years.

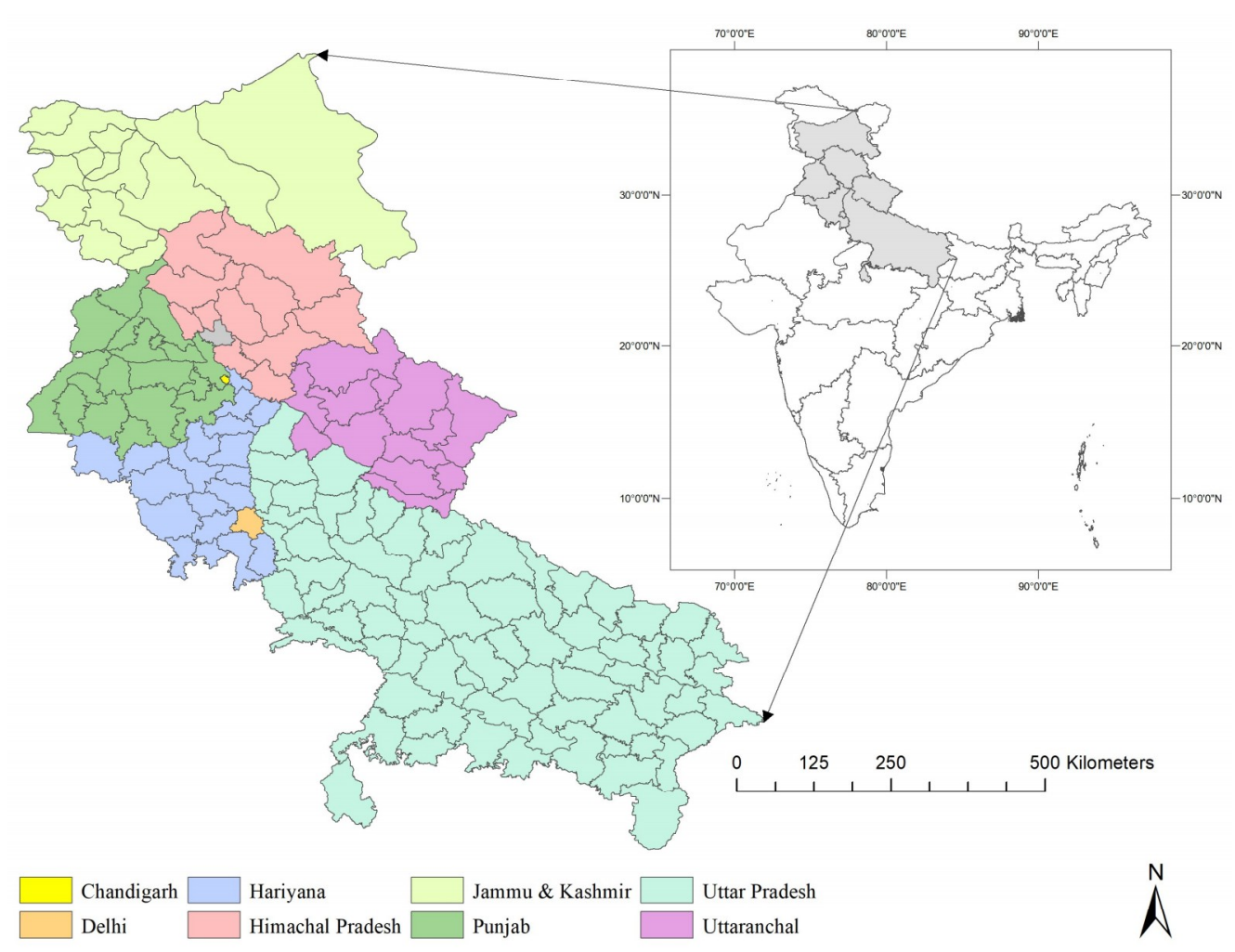

Figure 1. Map showing the selected states representing North India and the constituent districts (data for the gray-shaded district in Himachal Pradesh were unavailable).

Besides the trend and shift patterns of the selected variables at each of the four ENSO phases mentioned earlier, the all-year (century-wide) trend and shift patterns during the monsoon as well as during each of the monsoonal months were evaluated. For the temperature and PET trends and shifts, the monthly mean of the monsoon and of each of the monsoonal months were analyzed. 
For precipitation, the monthly totals were used. The annual and seasonal apportionment entropy were evaluated using the annual data-the sum of all the monthly means, and the seasonal data-the monthly means of each of the monsoonal months.

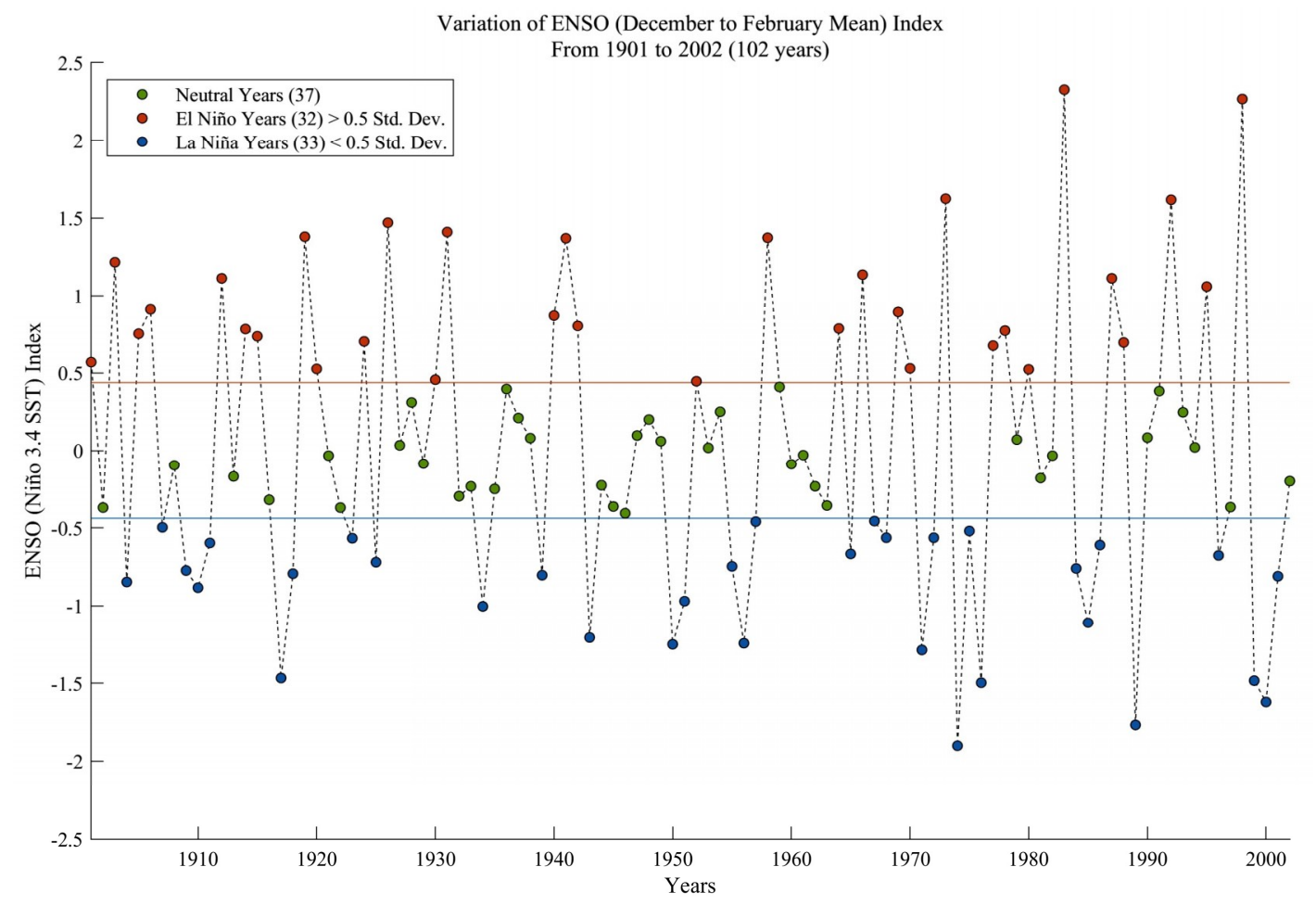

Figure 2. Plot showing the variation of El Niño Southern Oscillation (ENSO, Niño 3.4) index over the current study period. The orange (blue) horizontal line, which delineates 0.5 times the standard deviation above (below) the mean, represents the threshold for El Niño (La Niña).

\section{Methodology}

\subsection{Trend and Shift Tests}

Two nonparametric tests-namely, the Mann-Kendall (MK) trend test $[57,58]$ and the Pettitt's test [59] - were used to detect the presence of trends and shifts, respectively. A trend shows the past behavior of a variable that is more likely to be of a monotonic nature and may continue in the future unless an anomaly occurs $[64,65]$. The MK trend test is based on the null hypothesis that there is no trend in the time series. The test determines the direction of the trend, which can either be an increase (positive), decrease (negative), or absence of a trend, from the sign of a signum function. In contrast, a shift is an abrupt change in the data distribution, which remains unaltered until the next change occurs $[66,67]$. Pettitt's test detects the shift in a time series by testing the anomaly between the mean of two independent samples from the same time series. The direction of the shift, which can be either positive (increasing), negative (decreasing), or an absence of a shift, is determined from the maximum and minimum probability estimates based on the significance level used. Nonparametric tests are better suited for hydro-climatological data distributions since such data distributions are more likely to be nonstationary and nonlinear in nature. The resilience against missing data points and robustness against the initial assumption of a normal distribution makes nonparametric tests a preferred choice over traditional statistical tests that have an inherent assumption of nonstationarity and nonlinearity $[68,69]$. Both the tests have been recommended in earlier studies due to their advantages over the other test methods as well as for their higher accuracy. Further remarks about these tests can be found in the works of [70-73]. Several modified versions of the MK test, named MK2, MK3, and MK4, accounting for different types of autocorrelation or persistence, 
are found in the literature $[65,68,74]$. These modified MK tests were also utilized in this study to analyze the trends. However, the results did not produce noticeable differences from the original results. Hence, descriptions of such methods have been omitted from the study. The lack of noticeable differences from the original test method suggests that autocorrelation or persistence had minimal influence on the datasets used in the study.

To calculate the slope (rate of change or change per unit time) of the observed trends, the Theil-Sen approach (TSA) was employed $[75,76]$. The TSA is non-parametric in nature, which makes it appropriate to be applied in conjunction with the MK test. Moreover, the TSA determines the median slope of all possible pairs, which makes the test robust against possible outliers. Walker's test [77] was used to determine the global (field) significance of each of the eight states consisting of multiple districts. A confidence interval of $90 \%(p \leq 0.10)$ was used for the statistical significance tests performed in this study.

\subsection{Entropy Test}

Entropy measures the variance in the temporal distribution of a variable [78]. According to [60], entropy measures the dispersion (range), uncertainty, anomaly, and variation in data. Such a measure can help distinguish between trends of similar types based on their uniformity over time. A review of entropy applications in the field of hydrology and water resources can be found in the work of [78]. Several indices of entropy can be calculated to measure variability in data [79]. For example, while studying the dynamics in complex systems, such as climate, recent studies have used a new time domain termed natural time $[80,81]$ in which the entropy is defined as a dynamic property that captures the time arrow, while the corresponding entropy change under time reversal is used to identify the occurrence (from approaching state to critical state) of extreme scenarios including earthquakes [82,83], ENSO events [84,85], and quasi-biennial oscillations [86]. In this study, apportionment entropy was used to evaluate the variability in the annual and seasonal (monsoonal) temperature, precipitation, and PET data. The following formulations are based on the works of [60,78].

The total annual (seasonal) aggregate, $R$-aggregated over the study period of 102 years (over the 4 months of monsoon) — of a variable, (i.e., temperature, precipitation, and PET) can be expressed as:

$$
R=\sum_{i=1}^{n} r_{i}
$$

where $r_{i}$ is the annual aggregate amount of a variable during the $i$ th year of the study period (monthly amount of a variable during the $i$ th month of the season), with $i=1$ to 102 for annual apportionment ( $i=1$ to 4 for seasonal apportionment).

The apportionment entropy $(A E)$ of a variable can be written as:

$$
A E=-\sum_{i=1}^{n}\left(r_{i} / R\right) \log _{2}\left(r_{i} / R\right)
$$

The annual apportionment entropy $\left(A E_{a}\right)$ measured the temporal variability in the annual dispersion of the variable over the study period. Equation (2) denotes that when a variable was evenly distributed, on an annual scale, over the study period of 102 years, with a probability of $1 / 102$, $A E_{a}$ had the maximum value of $\log _{2}(102)$ (or 6.6724). If the apportionment occurred during only one out of the 102 years, with a probability of $1, A E_{a}$ would take the minimum value of zero.

Similarly, the seasonal apportionment entropy $\left(A E_{s}\right)$ for the monsoon season was calculated using the June through September monthly mean data. This value varied from zero to $\log _{2}(4)$ (or 2.0). $A E_{s}$ for all the districts were calculated for each of the 102 years during the study period. For the purpose of representation, the mean $A E_{S}$ of the 102 years for each of the districts are reported in the study. 


\section{Results and Discussion}

\subsection{Temperature Change Patterns}

\subsubsection{Changes Associated with ENSO}

The spatial distribution of trends suggested that the western regions, i.e., Chandigarh, Haryana, and Punjab, as well as a significant portion of Uttar Pradesh, experienced a decreasing trend in all the ENSO phases (Figure 3). States, such as Himachal Pradesh, Jammu and Kashmir, and Uttarkhand, did not show much of a presence of significant trends except during the El Niño years. The spatial distribution of districts with significant trends during the El Niño (La Niña) and non-La Niña (non-El Niño) years were found to be comparable. Districts with significant decreasing trends during the El Niño (La Niña) years were found to be the maximum (minimum) among the four ENSO phases analyzed in the study. An increasing trend was observed only during a neutral year. Table 1 summarizes the results in terms of the number of districts with significant trends. It can be inferred from the results that the El Niño years, compared to other phases of ENSO, had a higher influence on the decreasing trends in temperature during the monsoon season. The prolonged effect of El Niño on temperature variations of the Indian Ocean and the resulting heat fluxes among various land masses can be attributed as one of the major reasons for the observed variations $[44,46]$.

(a) El Niño years
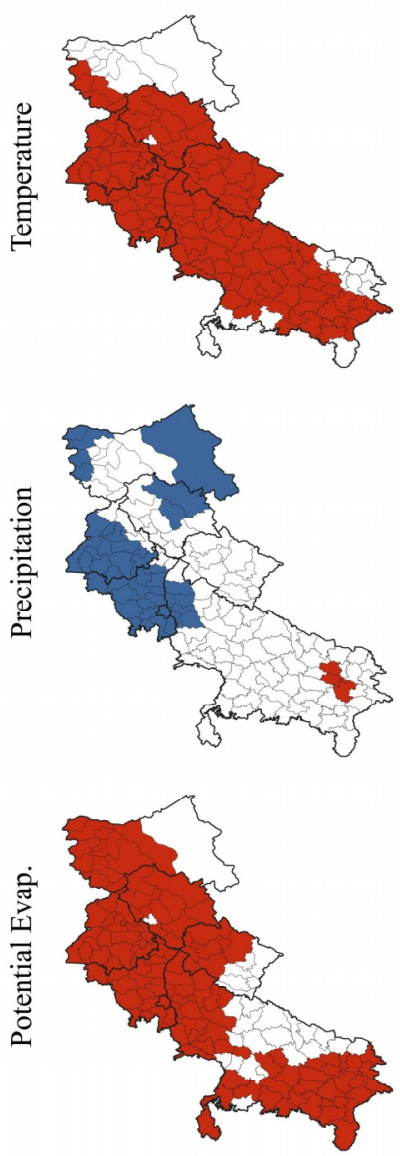

(b) La Niña years
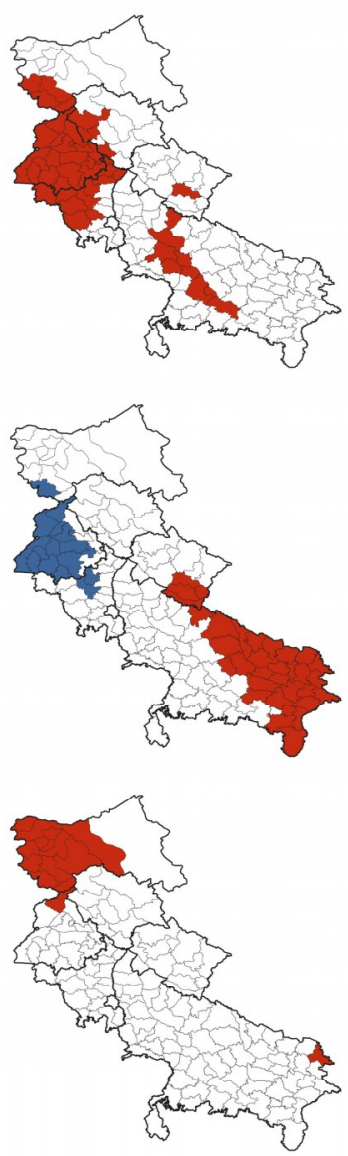

(c) Non-El Niño years
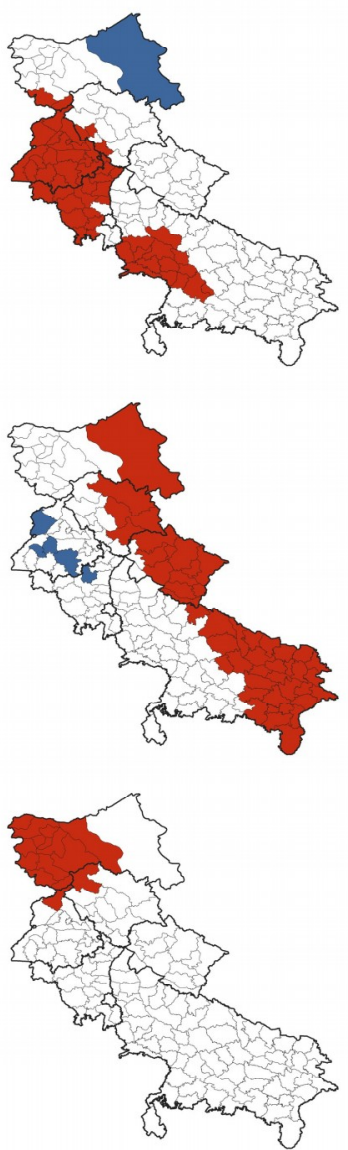

(d) Non-La Niña years
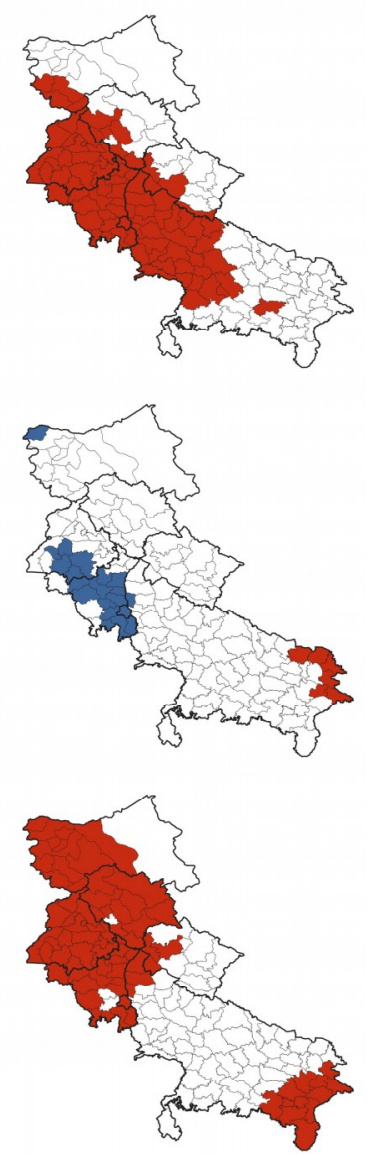

Figure 3. Maps showing the spatial distributions of districts with significant trends in the monsoon season under the Mann-Kendall (MK) test for temperature, precipitation, and potential evapotranspiration in the (a) El Niño, (b) La Niña, (c) non-El Niño, and (d) non-La Niña years. Blue (red) represents districts with increasing (decreasing) trends. 
The spatial pattern of shifts suggested that the El Niño (La Niña) and non-La Niña (non-El Niño) years had a similar influence on the study area. All the states-or a large portion of them except for Jammu and Kashmir, and Uttarkhand-had significant negative shifts during the El Niño and non-La Niña years (Figure 4). Districts in Uttarkhand and Uttar Pradesh, which did not show the presence of shifts during the El Niño or non-La Niña years, were found to be significant during the La Niña and non-El Niño years. This feature of the shift patterns suggested that the two opposing phases of ENSO influenced certain regions of North India in distinct ways (Figure 4). The El Niño (La Niña) years showed similar spatial patterns as the non-La Niña (non-El Niño) years. The maximum (minimum) number of districts with significant negative shifts was observed during the non-La Niña (La Niña) years (Table 1).

(a) El Niño years
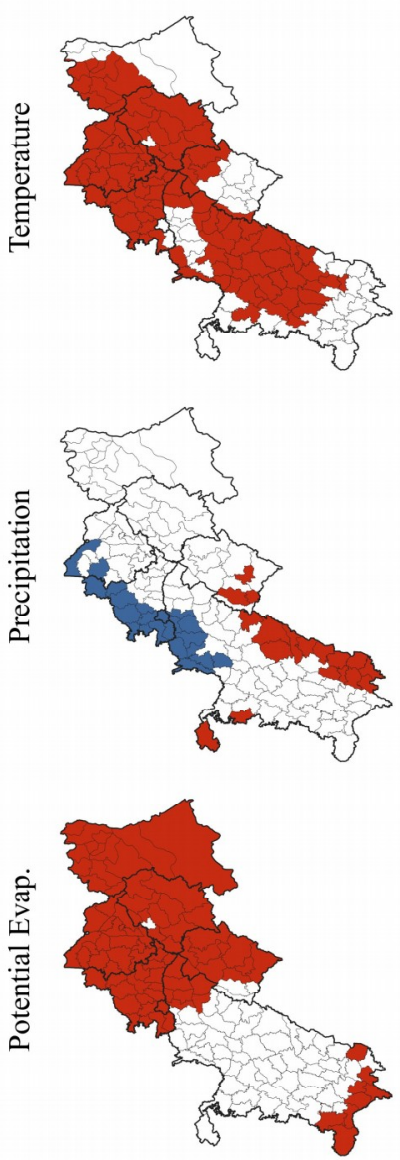

(b) La Niña years
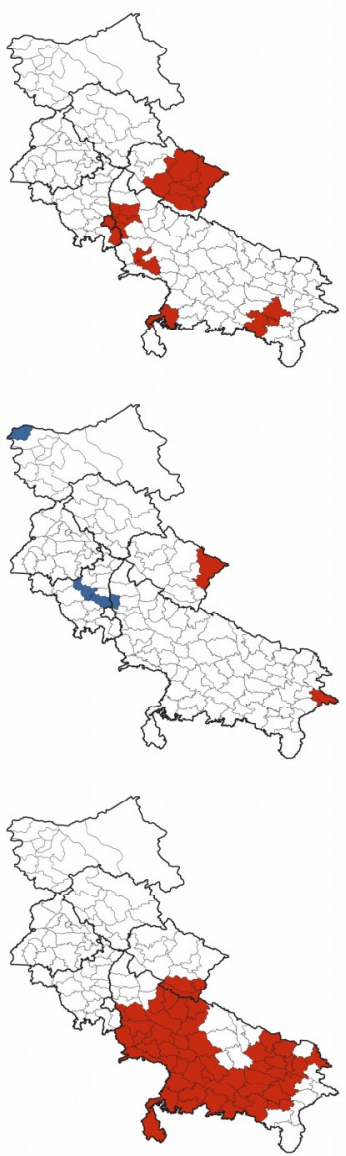

(c) Non-El Niño years
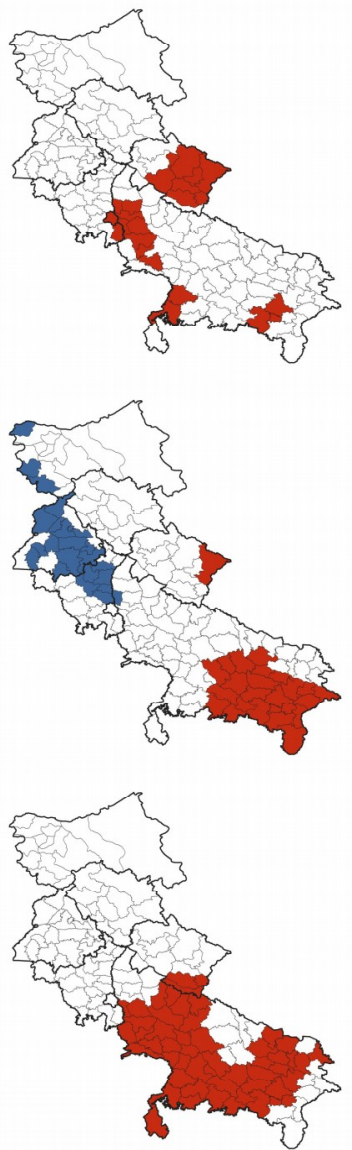

(d) Non-La Niña years
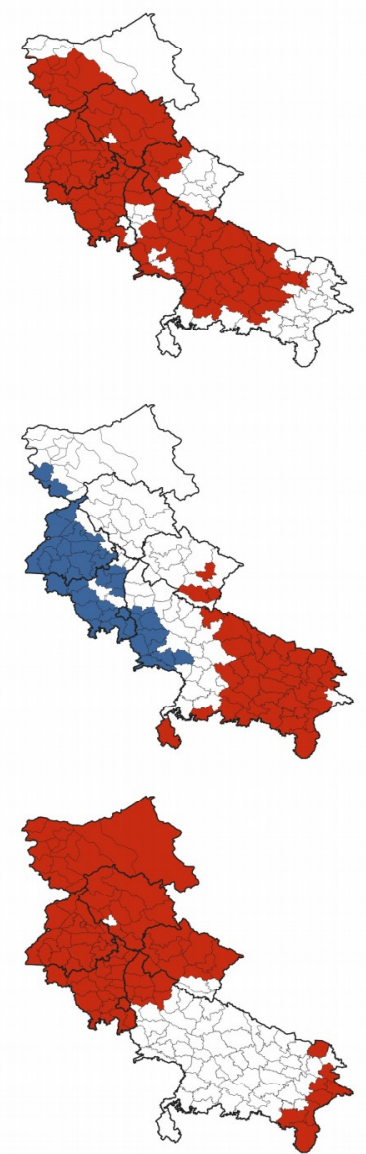

Figure 4. Maps showing the spatial distributions of districts with significant shifts in the monsoon season under the Pettitt's test for temperature, precipitation, and potential evapotranspiration in the (a) El Niño, (b) La Niña, (c) non-El Niño, and (d) non-La Niña years. Blue (red) represents districts with positive (negative) shifts. 
Table 1. The number of districts (out of a total of 146) with significant increasing or decreasing trends and shifts in temperature, precipitation, and potential evapotranspiration during the different ENSO phases.

\begin{tabular}{|c|c|c|c|c|c|c|c|c|c|}
\hline \multirow[b]{2}{*}{ Variable } & \multirow[b]{2}{*}{ Change Type } & \multicolumn{2}{|c|}{ El Niño Years } & \multicolumn{2}{|c|}{ La Niña Years } & \multicolumn{2}{|c|}{ Non-El Niño Years } & \multicolumn{2}{|c|}{ Non-La Niña Years } \\
\hline & & Increasing & Decreasing & Increasing & Decreasing & Increasing & Decreasing & Increasing & Decreasing \\
\hline \multirow{2}{*}{ Temperature } & Trends & - & 125 & - & 47 & 1 & 53 & - & 84 \\
\hline & Shifts & - & 99 & - & 20 & - & 23 & - & 102 \\
\hline \multirow{2}{*}{ Precipitation } & Trends & 43 & 3 & 16 & 33 & 5 & 47 & 20 & 6 \\
\hline & Shifts & 22 & 18 & 4 & 2 & 23 & 25 & 41 & 41 \\
\hline \multirow{2}{*}{ Pot. Evap. } & Trends & - & 120 & _- & 15 & _- & 15 & - & 78 \\
\hline & Shifts & - & 88 & - & 52 & - & 52 & - & 88 \\
\hline
\end{tabular}




\subsubsection{All-Year Change Patterns}

The all-year (century-wide) trend patterns suggested that the entire states of Haryana and Punjab, as well as the western regions of all the remaining states, experienced decreasing trends either during the entire four-month summer monsoon or in any of the monsoonal months (Figure 5). The eastern regions of Himachal Pradesh, Jammu and Kashmir, Uttarkhand, and Uttaranchal did not show a significant presence of trends. The monthly variation of trends showed that from June to September, the spatial location of districts with significant trends shifted from the southwest towards the north, then shifted back towards the southwest (Figure 5). This change in spatial distribution could be explained by the direction of the monsoon circulation, which carries humid summer winds from the southwest direction in June and sweeps across the Indian subcontinent by moving north; eventually, these winds move back to the southwest of India in September. Table 2 lists the number of districts with significant trends during the monsoon and in each of the monsoonal months. The range of TSA slopes during the monsoon and the monsoonal months also showed the overall inclination towards decreasing trends (Table 3). The TSA slopes suggest that the month of June experienced the highest variation in temperature over the study period. Decreasing trends in temperature in many parts of North India also were observed in the mean temperature trends from 1951 to 2010 by [26], which support the findings of the current study.
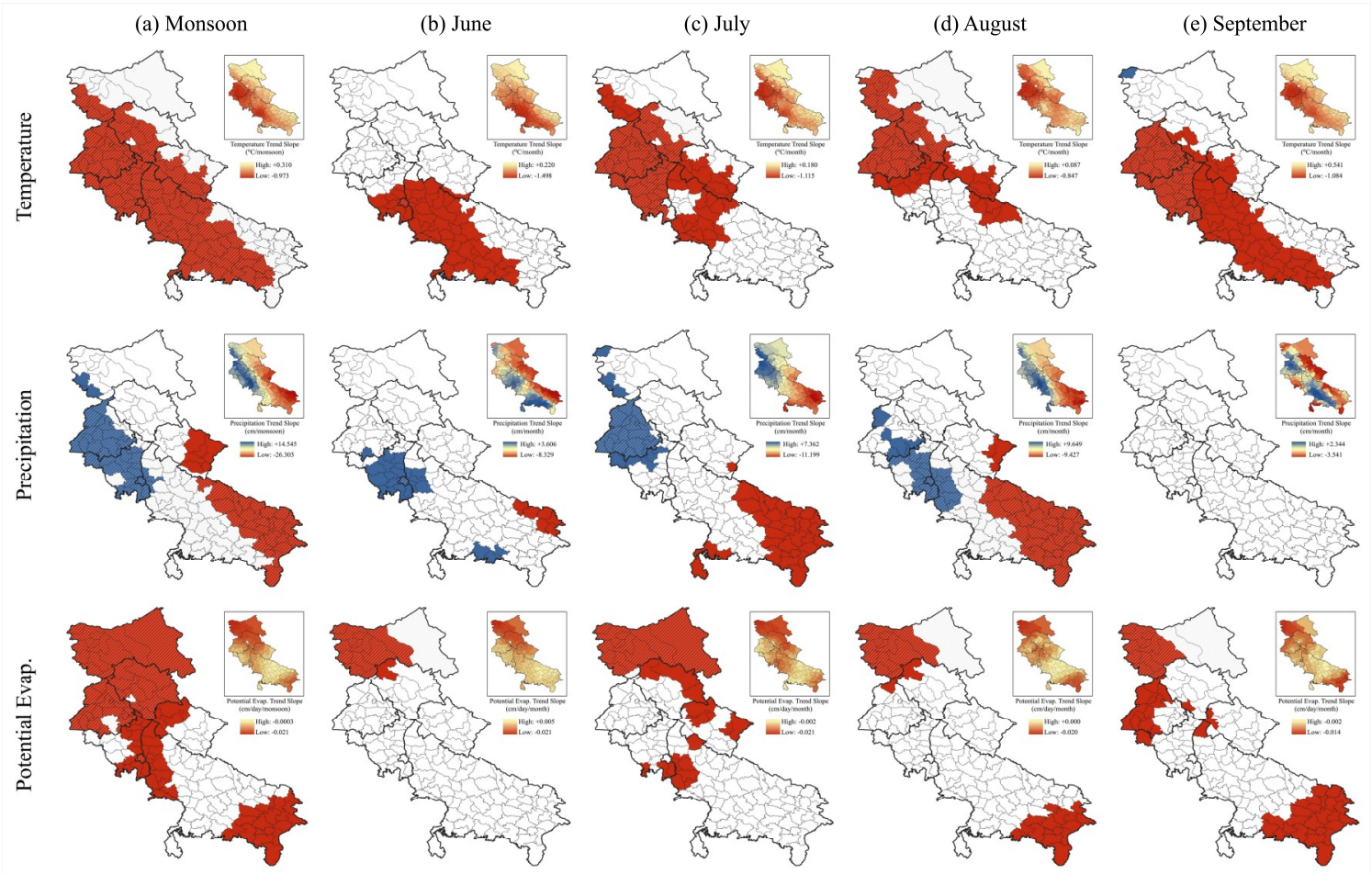

Figure 5. Maps showing the spatial distributions of districts with significant trends under the MK test for temperature, precipitation, and potential evapotranspiration in, (a) the monsoon, and the monsoonal months of (b) June, (c) July, (d) August, and (e) September. Blue (red) represents districts with increasing (decreasing) trends. The inset maps show the spatial dispersal of the slope values of the trends obtained from TSA. States with light gray hatches represent the presence of field significance. 
Table 2. The Number of districts (out of a total of 146) with significant increasing or decreasing trends and shifts in temperature, precipitation, and potential evapotranspiration during the monsoon and in each of the monsoonal months.

\begin{tabular}{|c|c|c|c|c|c|c|c|c|c|c|c|}
\hline \multirow[b]{2}{*}{ Variable } & \multirow[b]{2}{*}{ Change Type } & \multicolumn{2}{|c|}{ Monsoon } & \multicolumn{2}{|c|}{ June } & \multicolumn{2}{|c|}{ July } & \multicolumn{2}{|c|}{ August } & \multicolumn{2}{|c|}{ September } \\
\hline & & Increasing & Decreasing & Increasing & Decreasing & Increasing & Decreasing & Increasing & Decreasing & Increasing & Decreasing \\
\hline \multirow{2}{*}{ Temperature } & Trends & - & 109 & - & 49 & _ & 76 & _ & 60 & - & 92 \\
\hline & Shifts & - & 122 & - & 99 & - & 86 & - & 76 & 1 & 113 \\
\hline \multirow{2}{*}{ Precipitation } & Trends & 35 & 32 & 23 & 6 & 24 & 33 & 25 & 38 & - & _ \\
\hline & Shifts & 45 & 43 & 43 & 7 & 31 & 38 & 41 & 40 & - & 1 \\
\hline \multirow{2}{*}{ Pot. Evap. } & Trends & - & 93 & - & 14 & - & 31 & - & 31 & - & 53 \\
\hline & Shifts & _ & 140 & - & 93 & _- & 89 & _- & 113 & _- & 146 \\
\hline
\end{tabular}


Table 3. The range of all-year Theil-Sen approach (TSA) slopes of temperature, precipitation, and potential evapotranspiration during the monsoon and in each of the monsoonal months.

\begin{tabular}{llcccc}
\hline \multicolumn{5}{c}{ Variable (Slope) } & \multicolumn{5}{c}{ Monsoon } & June & July & August & September \\
\hline Temperature $\left({ }^{\circ} \mathrm{C} /\right.$ time unit) & -0.97 to +0.31 & -1.50 to +0.22 & -1.12 to +0.18 & -0.85 to +0.09 & -1.08 to +0.54 \\
Precipitation (cm/time unit) & -26.30 to +14.55 & -8.33 to +3.61 & -11.20 to +7.34 & -9.43 to +9.65 & -3.54 to +2.34 \\
Pot. Evap. (cm/day/time unit) & -2.56 to -0.04 & -0.63 to +0.16 & -0.65 to -0.06 & -0.62 to +0.00 & -0.42 to -0.06 \\
\hline
\end{tabular}

The all-year shift patterns suggested that except for a few districts in the eastern part of Jammu and Kashmir and Uttar Pradesh, the remainder of North India experienced negative shifts either during the monsoon or in any of the monsoonal months (Figure 6). Similar to the trends, the shift patterns showed a northbound movement followed by a southbound movement in districts having significant shifts during the individual monsoonal months. Table 2 summarizes the results in terms of the number of districts with significant shifts. Table 4 shows the earliest and latest shift along with the major intervals having a higher number of shift points in temperature during the study period. A comparison of the shift points (Table 4) with the ENSO indices (Figure 2) showed that most of the shift points coincided with the El Niño and non-La Niña years. Previous studies and historical events $[35,41]$, causing climate extremes, were found to be consistent with the major shift points detected in the current study. For both the trend and shift patterns, states with field significance were observed to vary across the months (Figures 5 and 6 ).
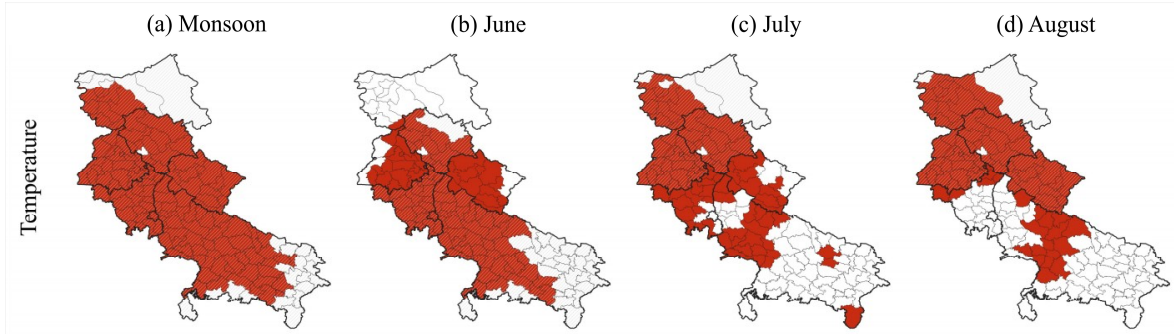

(e) September
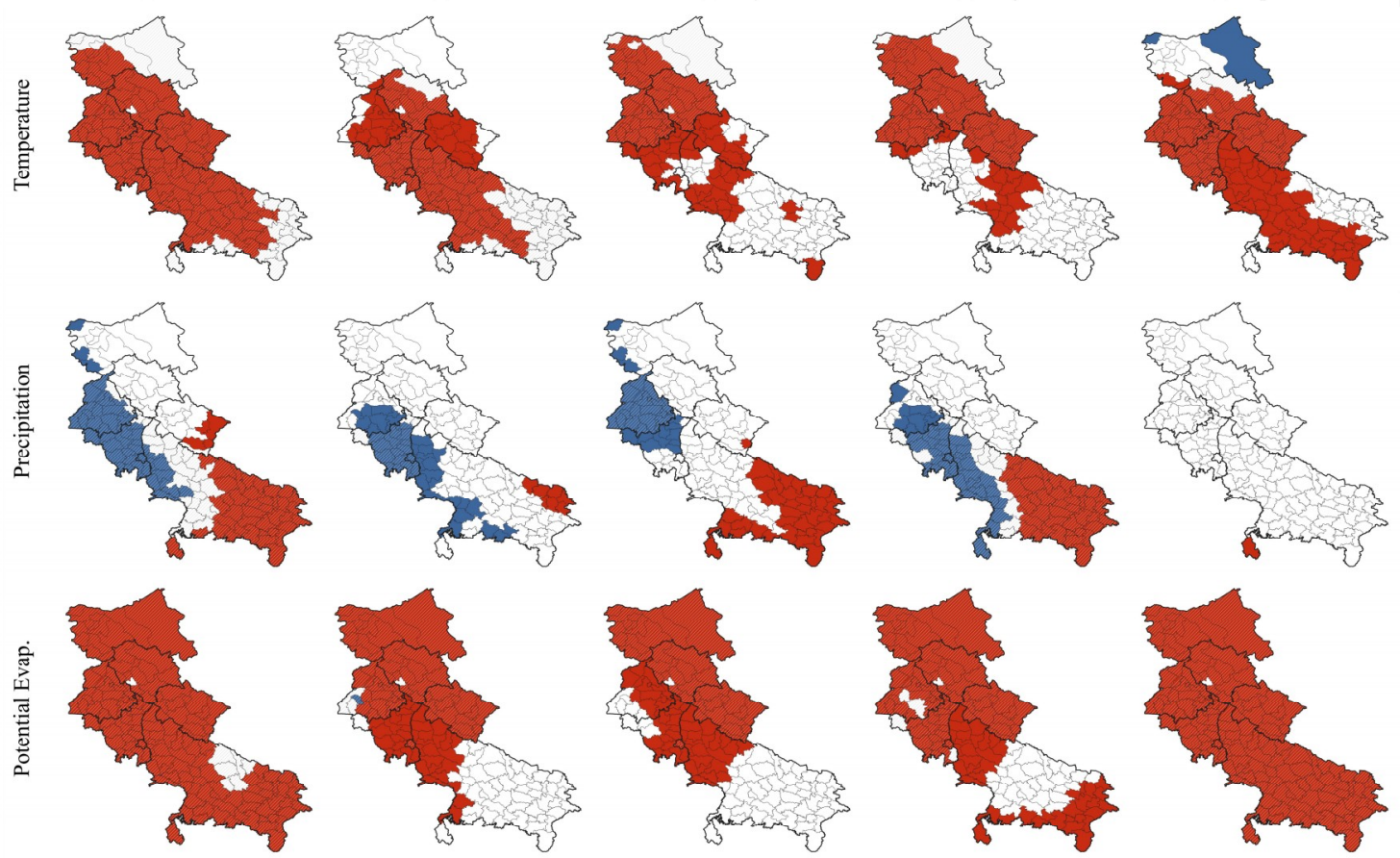

Figure 6. Maps showing the spatial distributions of districts with significant shifts under Pettitt's test for temperature, precipitation, and potential evapotranspiration in (a) monsoon, and the monsoonal months of (b) June, (c) July, (d) August, and (e) September. Blue (red) represents districts with positive (negative) shifts. States with light gray hatches represent the presence of field significance. 
Table 4. The location in time of the earliest and latest significant shift of temperature, precipitation, potential evapotranspiration. The major intervals, with years without significant shifts in between, show where the majority of the significant shift points were detected in the study.

\begin{tabular}{cccc}
\hline Variable & Earliest Shift & Latest Shift & Major Intervals \\
\hline \multirow{2}{*}{ Temperature } & \multirow{2}{*}{1908} & \multirow{2}{*}{1997} & $1915-1932$ \\
& & & $1947-1973$ \\
& \multirow{2}{*}{1905} & \multirow{2}{*}{1996} & $1985-1986$ \\
\hline \multirow{2}{*}{ Precipitation } & & $1908-1917$ \\
& & & $1920-1934$ \\
& \multirow{2}{*}{1920} & \multirow{2}{*}{1976} & $1980-1978$ \\
Pot. Evap. & & & $1920-1930$ \\
& & & $1941-1958$ \\
& &
\end{tabular}

\subsection{Precipitation Change Patterns}

\subsubsection{Changes Associated with ENSO}

A distinct separation across North India was observed between the districts with increasing and decreasing trends in the spatial patterns of trends. During the various ENSO phases, the western regions, i.e., Delhi, Haryana, and Punjab, a significant portion of Jammu and Kashmir, and a few districts in Himachal Pradesh and Uttar Pradesh, experienced increasing trends (Figure 3). Decreasing trends were localized in the eastern regions, i.e., significant portions of Himachal Pradesh, the entire state of Uttarkhand, and the eastern part of Uttar Pradesh. The maximum numbers of districts with increasing (decreasing) trends were observed during the El Niño (non-El Niño) years (Table 1). In some instances, the direction of the trends reversed when the ENSO phase changed from El Niño to non-El Niño. As suggested by previous studies, these variations could be explained by factors that either could strengthen or weaken the effects of ENSO on the monsoon $[48,49,87]$. Other studies suggest that the teleconnection has different correlations based on the time scales (i.e., interannual, quasi-decadal, or decadal), which might affect long-term trend patterns $[47,51,53]$.

Similar to the trend patterns, shift patterns of precipitation also showed a spatial separation between the districts with positive and negative shifts (Figure 4). Spatial patterns in the various ENSO phases showed that both the El Niño and neutral years played a significant role in the precipitation shift patterns across North India. In the various ENSO phases, the western regions, i.e., Delhi, Haryana, and Punjab, as well as a few western districts of Jammu and Kashmir and Uttar Pradesh, showed positive shifts (Figure 4). Negative shifts were observed only in the eastern part of Uttar Pradesh and in a few districts of Uttarkhand. This showed that North India experienced both positive and negative shifts during the various ENSO phases even though the shifts were spatially separated and localized to certain regions. In the precipitation trends, there were instances in which the direction of the trend reversed with the change of the ENSO phase from El Niño to La Niña; however, precipitation shift patterns did not show such a reversal in direction. The La Niña (non-La Niña) years had the minimum (maximum) number of districts with significant shifts (Table 1).

\subsubsection{All-Year Change Patterns}

In the all-year trend patterns, the western regions, i.e., Delhi, Haryana, and Punjab as well as a few western districts of Jammu and Kashmir, and Uttar Pradesh, experienced increasing trends either during the monsoon or in any of the monsoonal months (Figure 5). Decreasing trends were observed in the eastern districts of Uttarkhand and Uttar Pradesh and in a few of the western districts of Uttar Pradesh. (Figure 5). A greater tendency towards decreasing trends in the eastern regions was observed by [26]. Monthly trends followed similar spatial patterns, although the number of districts with trends 
varied significantly across the monsoonal months (Table 2). July and August showed a higher number of districts with significant trends compared to June. This monthly variation could be explained by the timing of the monsoon circulation. Since the monsoon season starts in June and ends in September, it can be inferred that the effects of the monsoon developed fully during July and August. Since the monsoon recedes in September, it might be possible that the change in wind direction does not result in causing significant change. This also was observed in the TSA slope values for September (Figure 5), as the slopes during September did not follow any spatial pattern; rather, they were quite arbitrary in nature (Table 3). Comparison of TSA values suggested that July and August experienced a higher change over the study period.

Similar to the all-year trend patterns, the all-year shift patterns also showed a separation in the locations of districts with significant positive and negative shifts (Figure 6). Southwestern districts of Uttar Pradesh showed positive shifts but did not show increasing trends in the trend pattern. Similar to the trend pattern, September did not show significant shifts except for a single district with negative shift in Uttar Pradesh. The northbound movement followed by a southbound movement of the districts with significant trends (shifts) occurring from June to August could also be explained by the direction of the monsoon circulation as discussed earlier. The monthly variation (Table 2) showed a similar generic spatial pattern of increasing and negative shifts-for the western and the eastern regions, respectively-but varied significantly in terms of the number of districts with significant shifts (Figure 6). Table 4 shows the locations of the major shift points in precipitation during the study period. The shift points observed mostly coincided with the non-La Niña years, as was observed by comparing the results with Figure 2. States with field significance were observed to vary across the various monsoonal months in both the trend and shift patterns.

\subsection{Potential Evapotranspiration Change Patterns}

\subsubsection{Changes Associated with ENSO}

All the states of North India, or a significant portion of them, were observed to experience decreasing trends during the El Niño years in the PET trend patterns (Figure 3). The states showed hardly any significant trends during the La Niña and non-El Niño years, except for a portion of Jammu and Kashmir and a district each in Himachal Pradesh, Punjab, and Uttar Pradesh. This suggested that the effect of ENSO phases on PET was not evenly distributed across the districts. With fewer districts of significance in Uttar Pradesh, the non-La Niña years had a similar spatial pattern as the El Niño years. The La Niña years and non-El Niño years also showed similar spatial patterns. The maximum (minimum) number of districts with decreasing trends was observed during the El Niño (La Niña and non-El Niño) years (Table 1). Similar to the temperature trends, the effect of neutral years, compared to the El Niño and La Niña years, on the change patterns of PET was observed to be less significant (Figure 3). Previous studies have suggested that El Niño has a much higher potential of altering the evaporation configuration around Indian Ocean basins, which eventually could affect the temperature of those basins [54], as was found in the current study, especially during the El Niño and non-La Niña years.

The spatial distribution of PET shift patterns revealed that all the districts, except for a few districts in Uttar Pradesh, experienced negative shifts either during the El Niño or the La Niña years (Figure 4). The comparisons revealed that the neutral phases did not play a significant role in the shifts, as the El Niño (La Niña) years had exactly the same spatial patterns as the non-La Niña (Non-El Niño) years. This suggested that the districts experiencing shifts during the El Niño and La Niña years were mutually exclusive (Figure 4). The El Niño (non-La Niña) years had a higher number of districts with negative shifts compared to the La Niña (non-El Niño) years (Table 1). In the PET trend patterns, the same districts showed the presence of trends during both the El Niño and La Niña years. This was not observed in the shift patterns of PET, which suggests that the El Niño and La Niña years 
were associated with or influenced the PET shifts of the northern and southern regions of North India mutually exclusively.

\subsubsection{All-Year Change Patterns}

The all-year trend patterns revealed that most of the decreasing trends were observed in the northwestern regions, i.e., Himachal Pradesh, Punjab, and Jammu and Kashmir, as well as in the southeastern districts of Uttar Pradesh either during the monsoon or in any of monsoonal months (Figure 5). The central part of Uttar Pradesh and the entire state of Uttarkhand did not show much presence of trends in any of the monsoonal months. The monthly variation (Table 2) of trend patterns showed that June and July had districts with decreasing trends, mostly in the northern regions; meanwhile, August and September had decreasing trends both in the northern and southern regions (Figure 5). Compared to the temperature and precipitation trend patterns, the change in PET across the months did not follow a northbound and a subsequent southbound movement. However, northern regions showed a higher number of districts with trends in the first half of the season, while southern regions had a higher number of districts with trends in the second half of the season. The TSA values (Table 3) suggested that June experienced the greatest change in PET over the study period (Figure 3). Moreover, the results suggested that the decreasing trend in temperature did not necessarily cause a decreasing trend in PET - at least not during all the months of the monsoon (Figure 5). The decreasing trends in PET and its anomaly with temperature trends could be explained by the stressed crops and reduced vegetation across India [88,89].

In the all-year shift patterns, all the districts of North India were observed to experience negative shifts either during monsoon or in any of the monsoonal months. Some mid-southeastern and southeastern districts of Uttar Pradesh did not show the presence of a trend during June, July, and August (Figure 6). However, during September, all of North India experienced negative shifts. Except for one district in June, which could be considered as an anomaly, no presence of positive shifts was observed across the study period during the monsoon season or in any of the monsoonal months. The locations of the major shift points in PET during the study period are shown in Table 4. Comparing the results with Figure 2 showed that the shift points coincided with both the El Niño and La Niña years, but not so much with the neutral years. Districts all across North India experienced shifts, while mostly northern and southern regions showed the presence of trends-which was a significant difference between the PET trend (Figure 3) and PET shift patterns (Figure 5). For both the all-year trend and shift patterns, states with field significance were observed to vary across the monsoonal months.

\subsection{Entropy}

\subsubsection{Temperature Entropy}

The $A E_{a}$ suggested that the temperature change was distributed quite evenly over the study period (102 years) across most of North India (Table 5), except for a few northeastern regions that experienced apportionment over approximately 98 years (Figure 7). The spatial distribution suggested that the southeastern and northwestern regions had higher $A E_{a}$ values compared to the rest of the study area. The $A E_{S}$ of temperature suggested that the temperature change also was quite uniform across the monsoonal months, with the lowest $A E_{s}$ value referring to a change apportioned over 3.86 months (Table 5). The spatial pattern of $A E_{s}$ was found to be more dispersed across the different districts compared to the $A E_{a}$ pattern. This variation was more prominent in the comparison between the standardized $A E_{a}$ and $A E_{s}$ values (Figure 7). For most districts, annual variation was observed to be close to the mean value, which was not the case for seasonal variation. The results showed that a variation in $A E_{s}$ was much higher than in $A E_{a}$, even among nearby districts. This suggests that the different months of monsoon affected change patterns differently for each district; however, on an annual scale, the change was much more uniform across years. A comparison between the trends in temperature (Figure 3) and the entropy distribution of temperature (Figure 7) suggested that many 
districts with significant decreasing trends had higher entropy values, indicating an even distribution of change over the study period.

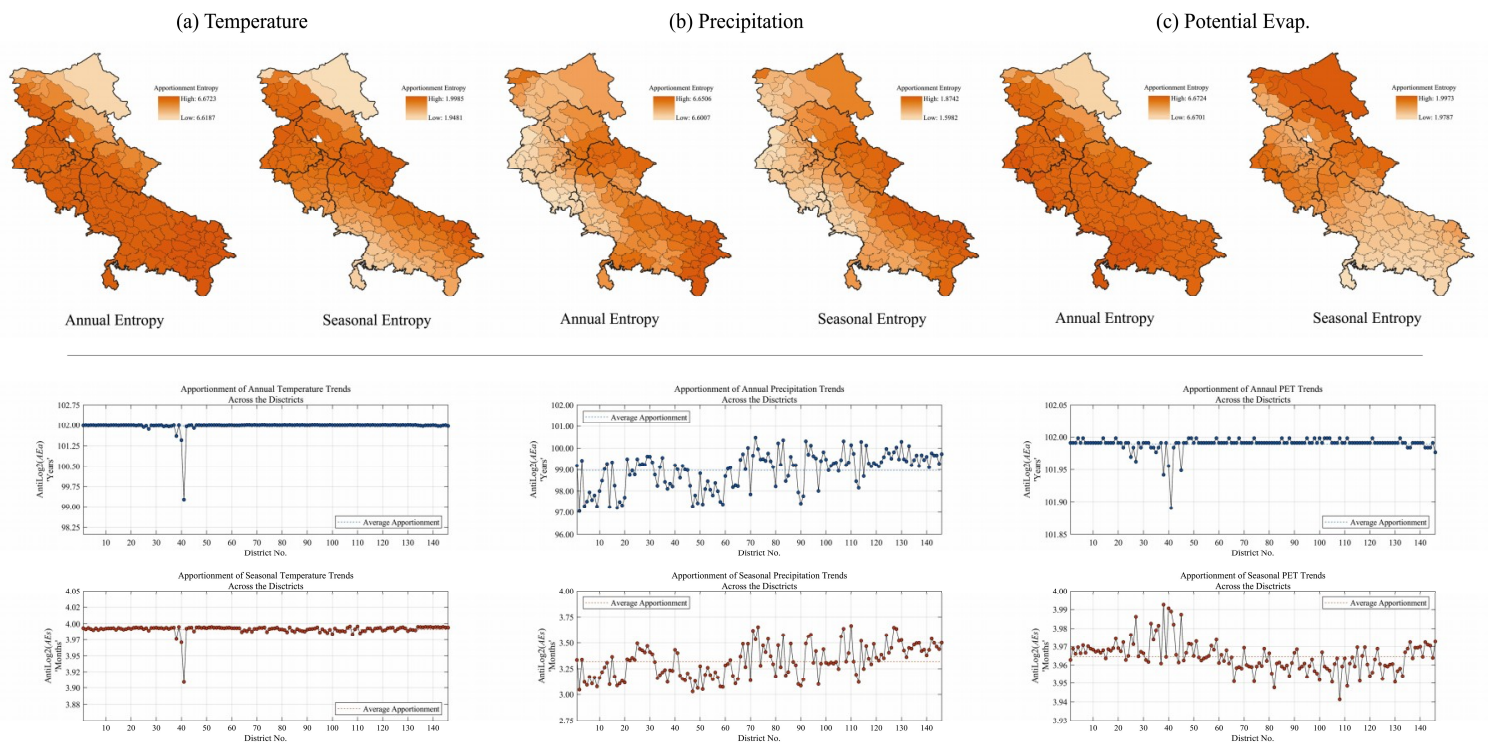

Figure 7. Maps (at the top) showing the spatial distribution of the annual and seasonal apportionment entropy for (a) temperature, (b) precipitation, and (c) potential evapotranspiration. Plots (at the bottom) showing the variation in the standardized annual and seasonal variation of the apportionment entropy index across all the districts for the chosen variables. The supplementary material (Table S1) contains the names and numbers of the individual districts in each of the states.

\subsubsection{Precipitation Entropy}

The values of the precipitation $A E_{a}$ were found to be apportioned over approximately 97 to 100 years (Table 5) across the districts, which suggested that the variation in precipitation was less evenly distributed over the study period compared to the variation in temperature (Figure 7). On the other hand, the $A E_{S}$ of precipitation were found to be apportioned over 3.00 to 3.67 months, indicating higher monthly variation across the monsoonal season (Table 5). The spatial distribution of both the $A E_{a}$ and $A E_{s}$ were found to be similar for the mid-eastern and southeastern regions having higher entropy values, and the mid-western and northwestern regions having lower entropy values. This similarity of apportionment was evident when comparing the standardized $A E_{a}$ and $A E_{s}$ values (Figure 7), which suggested that the nearby districts had similar temporal variations. A comparison between the precipitation trend patterns (Figure 5) and precipitation entropy distribution (Figure 7) suggested that districts with increasing (decreasing) trends had lower (higher) entropy. This could be an important feature when trying to understand trend patterns. The results imply that even though some districts showed increasing trends, their temporal distribution was less evenly distributed over the years, as well as across the monsoonal months, when compared to the districts with decreasing trends. This suggested that the overall trend pattern of precipitation has decreased with much greater uniformity, compared to the increase, during the study period. This could be an important insight regarding the increasing trends observed during the El Niño years. Although the difference in apportionment was found to be only three years (97 and 100 years for districts with the lowest and highest entropy, respectively), the results certainly showed how apportionment entropy could explain trend patterns with greater insight. 
Table 5. The range of annual and seasonal apportionment entropy of temperature, precipitation, and potential evapotranspiration across the study period of 102 years and over four months of monsoon.

\begin{tabular}{ccccc}
\hline Variable & \multicolumn{2}{c}{ Annual Apportionment Entropy (AE $\mathbf{a}$ ) } & \multicolumn{2}{c}{ Seasonal Apportionment Entropy (AE $)$} \\
\hline & $\begin{array}{c}\text { Range } \\
\text { (from 0 to 6.6725) }\end{array}$ & $\begin{array}{c}\text { Apportionment } \\
\text { (Years) } \\
\text { (from 1 to 102) }\end{array}$ & $\begin{array}{c}\text { Range } \\
\text { (from 0 to 2) }\end{array}$ & $\begin{array}{c}\text { Apportionment } \\
\text { (Months) } \\
\text { (from 1 to 4) }\end{array}$ \\
\hline Temperature & 6.6187 to 6.6723 & 98.27 to 101.99 & 1.9481 to 1.9985 & 3.86 to 3.99 \\
Precipitation & 6.6007 to 6.6506 & 97.05 to 100.47 & 1.5982 to 1.8742 & 3.02 to 3.67 \\
Pot. Evap. & 6.6701 to 6.6724 & 101.84 to 101.99 & 1.9787 to 1.9973 & 3.94 to 3.99 \\
\hline
\end{tabular}

\subsubsection{Potential Evapotranspiration Entropy}

On an annual scale, the $A E_{a}$ of PET showed that the variations observed were quite evenly distributed (apportionment of approximately 102 years) over the study period (Table 5). The $A E_{s}$ of PET showed higher values of apportionment over almost all the months of monsoon; however, the spatial distribution was found to be quite different than what was observed in the $A E_{a}$ (Figure 7). Even though the actual range within which the values varied (1.9787 to 1.9973) was quite narrow (Table 5), the variation was quite high among the adjacent districts. The results showed that the spatial pattern of districts with higher and lower apportionment indices was quite opposite in the $A E_{a}$ and $A E_{s}$. Higher $A E_{a}$ values were observed in the mid-western and southern regions, while the northeastern regions showed lower $A E_{a}$ values. This pattern was reversed in the $A E_{s}$ distribution (Figure 7). The reversed behavior was more evident when comparing the standardized $A E_{a}$ and $A E_{s}$ values (Figure 7). Although both the annual and the seasonal variations suggested an even distribution temporally, the reversal in their spatial distribution suggested that the variation in PET during monsoonal months was opposite from the long-term annual variation. A comparison of PET trend patterns (Figure 5) and PET entropy distribution (Figure 7) revealed that many of the districts with significant decreasing trends showed higher $A E_{a}$ values, indicating that the change was fairly even.

The analyses of entropy for each of the variables showed how the change patterns were distributed temporally across the years and the monsoon season. In the cases when a variable experienced both the increasing and decreasing trends, the entropy revealed if one of the trends was more prevalent over the years (or across the season) or both had similar temporal distribution. Thus, the conjunction of the entropy analysis with the trend test (coupled with slope detection) provides greater insight into the nature of a trend.

\section{Conclusions}

In this study, three hydro-climatological variables, i.e., temperature, precipitation, and PET, were analyzed over century-wide data (from 1901 to 2002) to evaluate the influence of various ENSO phases on the change patterns across North India during the monsoon season. Trend and shift patterns of 146 districts in eight North Indian states were analyzed, and the annual and the seasonal (monsoonal) apportionment entropy that quantified the temporal distribution of the change patterns were evaluated. Besides the effects of ENSO, the all-year (century-wide) change patterns were analyzed to determine the effect of each of the monsoonal months on the long-term patterns. Results suggested that the El Niño years, compared to the La Niña and neutral years, had a much greater influence on the change patterns of the variables. The all-year change patterns suggested a significant decrease in the temperature and PET trends and shifts across North India, while the precipitation change patterns (both increasing and decreasing) were found to be region-specific. The entropy analyses suggested that the highest variation in the long-term change pattern occurred in precipitation data, whereas temperature and PET experienced more variation during the monsoon season compared to changes over the years.

Major physical and dynamic relationships affecting the monsoon season due to the change in ENSO phases in Indian subcontinent were compiled and discussed in this study based on the previous 
literature. By analyzing multiple hydro-climatological variables of North India, the study illustrated how various variables can be affected by the different phases of ENSO. Climate researchers and policymakers may find the results useful to understand the variability resulting from the various ENSO phases during the north Indian monsoon season. Such understanding may help devise strategies to mitigate the adverse effects of climate extremes.

Supplementary Materials: The following are available online at http:/ / www.mdpi.com/2073-4441/11/2/189/s1, Table S1: Names and numbers of the individual districts in each of the states.

Author Contributions: A.K. and S.A. conceptualized and supervised the work; M.B. contributed to analyzing the data; K.A.T. compiled the analyses and produced the results; the manuscript was written by the K.A.T., A.K., and S.A.

Funding: This research received no external funding.

Acknowledgments: The authors would like to acknowledge the Geological Survey of India, India Water Portal, and National Oceanic and Atmospheric Administration for providing important information and the data used in the study.

Conflicts of Interest: The authors declare no conflicts of interest.

\section{References}

1. Diffenbaugh, N.S.; Swain, D.L.; Touma, D. Anthropogenic warming has increased drought risk in California. Proc. Natl. Acad. Sci. USA 2015, 112, 3931-3936. [CrossRef]

2. Seager, R.; Hoerling, M.; Schubert, S.; Wang, H.; Lyon, B.; Kumar, A.; Nakamura, J.; Henderson, N. Causes of the 2011-2014 California drought. J. Clim. 2015, 28, 6997-7024. [CrossRef]

3. Williams, A.P.; Seager, R.; Abatzoglou, J.T.; Cook, B.I.; Smerdon, J.E.; Cook, E.R. Contribution of anthropogenic warming to California drought during 2012-2014. Geophys. Res. Lett. 2015, 42, 6819-6828. [CrossRef]

4. Yoon, J.H.; Wang, S.S.; Gillies, R.R.; Kravitz, B.; Hipps, L.; Rasch, P.J. Increasing water cycle extremes in California and in relation to ENSO cycle under global warming. Nat. Commun. 2015. [CrossRef]

5. Griffin, D.; Anchukaitis, K.J. How unusual is the 2012-2014 California drought? Geophys. Res. Lett. 2014, 41, 9017-9023. [CrossRef]

6. Robeson, S.M. Revisiting the recent California drought as an extreme value. Geophys. Res. Lett. 2015, 42, 6771-6779. [CrossRef]

7. Wei, J.; Jin, Q.; Yang, Z.; Dirmeyer, P.A. Role of ocean evaporation in California droughts and floods. Geophys. Res. Lett. 2016, 6554-6562. [CrossRef]

8. Shukla, S.; Safeeq, M.; AghaKouchak, A.; Guan, K.; Funk, C. Temperature impacts on the water year 2014 drought in California. Geophys. Res. Lett. 2015, 42, 4384-4393. [CrossRef]

9. Bhandari, S.; Kalra, A.; Tamaddun, K.; Ahmad, S. Relationship between Ocean-Atmospheric Climate Variables and Regional Streamflow of the Conterminous United States. Hydrology 2018, 5, 30. [CrossRef]

10. Intergovernmental Panel on Climate Change (IPCC). Climate Change 2013: The Physical Science Basis; IPCC: Geneva, Switzerland, 2013; p. 33. [CrossRef]

11. Carrier, C.; Kalra, A.; Ahmad, S. Long-range precipitation forecast using paleoclimate reconstructions in the western United States. J. Mt. Sci. 2016, 13, 614-632. [CrossRef]

12. Dirmeyer, P.A.; Brubaker, K.L. Evidence for trends in the northern hemisphere water cycle. Geophys. Res. Lett. 2006, 33, L14712. [CrossRef]

13. Huntington, T.G. Evidence for intensification of the global water cycle: Review and synthesis. J. Hydrol. 2006, 319, 83-95. [CrossRef]

14. Kramer, R.; Bounoua, L.; Zhang, P.; Wolfe, R.; Huntington, T.; Imhoff, M.; Thome, K.; Noyce, G. Evapotranspiration Trends over the Eastern United States during the 20th Century. Hydrology 2015, 2, 93-111. [CrossRef]

15. Levis, S.; Foley, J.A.; Pollard, D. Large-scale vegetation feedbacks on a doubled $\mathrm{CO}_{2}$ climate. J. Clim. 2000, 13, 1313-1325. [CrossRef]

16. Bounoua, L.; Hall, F.G.; Sellers, P.J.; Kumar, A.; Collatz, G.J.; Tucker, C.J.; Imhoff, M.L. Quantifying the negative feedback of vegetation to greenhouse warming: A modeling approach. Geophys. Res. Lett. 2010, 37, L23701. [CrossRef] 
17. Tamaddun, K.; Kalra, A.; Ahmad, S. Potential of rooftop rainwater harvesting to meet outdoor water demand in arid regions. J. Arid Land 2018, 10, 68-83. [CrossRef]

18. Sellers, P.J.; Field, C.B.; Jensen, T.G.; Bounoua, L.; Collatz, G.J.; Randall, D.A.; Dazlich, D.A.; Los, S.O.; Berry, J.A.; Fung, I. Comparison of radiative and physiological effects of doubled atmospheric $\mathrm{CO}_{2}$ on climate. Science 1996, 271, 1402-1406. [CrossRef]

19. Guillevic, P.; Koster, R.D.; Suarez, M.J.; Bounoua, L.; Collatz, G.J.; Los, S.O.; Mahanama, S.P.P. Influence of the interannual variability of vegetation on the surface energy balance-A global sensitivity study. J. Hydrometeorol. 2002, 3, 617-629. [CrossRef]

20. Bonan, G.B. Forests and climate change: Forcings, feedbacks, and the climate benefits of forests. Science 2008, 320, 1444-1449. [CrossRef]

21. Tiwari, P.R.; Kar, S.C.; Mohanty, U.C.; Dey, S.; Kumari, S.; Sinha, P. Seasonal prediction skill of winter temperature over North India. Theor. Appl. Climatol. 2016, 124, 15-29. [CrossRef]

22. Tiwari, P.R.; Kar, S.C.; Mohanty, U.C.; Dey, S.; Kumari, S.; Sinha, P.; Raju, P.; Shekhar, M.S. Simulations of Tropical Circulation and Winter Precipitation over North India: An Application of a Tropical Band Version of Regional Climate Model (RegT-Band). Pure Appl. Geophys. 2016, 173, 657-674. [CrossRef]

23. Khare, D.; Mondal, A.; Kundu, S.; Mishra, P.K. Climate change impact on soil erosion in the Mandakini River Basin, North India. Appl. Water Sci. 2016. [CrossRef]

24. Singh, Y. Social Science Textbook for Class IX Geography; VK Publications: New Delhi, India, 2010; ISBN 978-81-89611-15-6.

25. Dimri, A.P. Relationship between ENSO phases with Northwest India winter precipitation. Int. J. Climatol. 2013, 33, 1917-1923. [CrossRef]

26. Rathore, L.S.; Attri, S.D.; Jaswal, A.K. State level climate change trends in India. Environ. Meteorol. 2013, 1,11 .

27. Abeysingha, N.S.; Singh, M.; Sehgal, V.K.; Khanna, M.; Pathak, H. Analysis of trends in streamflow and its linkages with rainfall and anthropogenic factors in Gomti River basin of North India. Theor. Appl. Climatol. 2016, 123, 785-799. [CrossRef]

28. Singh, S. India: Lonely Planet Guide; Lonely Planet: Gurgaon, India, 2003; ISBN 1-74059-421-5.

29. Kaul, H. Rediscovery of Ladakh; Indus Publishing: New Delhi, India, 1998; ISBN 9788173870866.

30. Rowell, G. Many people come, looking, looking; Mountaineers: Seattle, WA, USA, 1980; ISBN 9780916890865.

31. Datta, R.; Gupta, M. Synoptic study of the formation and movements of Western Depressions. Ind. J. Meteorol. Geophys. India 1968, 18, 45-50.

32. Dimri, A. Models to improve winter minimum surface temperature forecasts, Delhi, India. Meteorol. Appl. 2004, 11, 129-139. [CrossRef]

33. Wang, B. The Asian Monsoon; Springer: Berlin, Germany, 2006; ISBN 3-540-40610-7.

34. Ju, J.; Slingo, J. The Asian summer monsoon and ENSO. Quart. J. R. Meteorol. Soc. 1995, 121, $1133-1168$. [CrossRef]

35. Kumar, K.; Rajagopalan, B.; Cane, M. On the weakening relationship between the Indian monsoon and ENSO. Science 1999, 284, 2156-2159. [CrossRef]

36. Tamaddun, K.A.; Kalra, A.; Bernardez, M.; Ahmad, S. Multi-Scale Correlation between the Western U.S. Snow Water Equivalent and ENSO/PDO Using Wavelet Analyses. Water Resour. Manag. 2017, 31, 2745-2759. [CrossRef]

37. Ropelewski, C.F.; Halpert, M.S. North American precipitation and temperature patterns associated with El-Niño-Southern Oscillation (ENSO). Mon. Weather Rev. 1986, 114, 2165-2352. [CrossRef]

38. Kahya, E.; Dracup, J.A. U.S. streamflow patterns in relation to the El Niño/ Southern Oscillation. Water Resour. Res. 1993, 29, 2491-2503. [CrossRef]

39. Tamaddun, K.A.; Kalra, A.; Ahmad, S. Wavelet analysis of western U.S. streamflow with ENSO and PDO. J. Water Clim. Chang. 2017, 1-15. [CrossRef]

40. Sagarika, S.; Kalra, A.; Ahmad, S. Pacific Ocean and SST and Z500 climate variability and western U.S. seasonal streamflow. Int. J. Climatol. 2016, 36, 1515-1533. [CrossRef]

41. Kumar, K.; Rajagopalan, B.; Hoerling, M.; Bates, G.; Cane, M. Unraveling the Mystery of Indian Monsoon Failure during El Niño. Science 2006, 314, 115-119. [CrossRef]

42. Webster, P.J.; Yang, S. Monsoon and ENSO: Selectively interactive systems. Q. J. R. Meteorol. Soc. 1992, 118, 877-926. [CrossRef] 
43. Ashok, K.; Guan, Z.; Yamagata, T. Impact of the Indian Ocean dipole on the relationship between the Indian monsoon rainfall and ENSO. Geophys. Res. Lett. 2001, 28, 4499-4502. [CrossRef]

44. Wang, P.; Clemens, S.; Beaufort, L.; Braconnot, P.; Ganssen, G.; Jian, Z.; Kershaw, P.; Sarnthein, M. Evolution and variability of the Asian monsoon system: State of the art and outstanding issues. Quat. Sci Rev. 2005, 24, 595-629. [CrossRef]

45. Yang, J.; Liu, Q.; Xie, S.P.; Liu, Z.; Wu, L. Impact of the Indian Ocean SST basin mode on the Asian summer monsoon. Geophys. Res. Lett. 2007, 34,1-5. [CrossRef]

46. Xie, S.P.; Hu, K.; Hafner, J.; Tokinaga, H.; Du, Y.; Huang, G.; Sampe, T. Indian Ocean capacitor effect on Indo-Western Pacific climate during the summer following El Niño. J. Clim. 2009, 22, 730-747. [CrossRef]

47. Torrence, C.; Webster, P. Interdecadal changes in the ENSO-monsoon system. J. Clim. 1999, 12, $2679-2690$. [CrossRef]

48. Saji, N.H.; Goswami, B.N.; Vinayachandran, P.N.; Yamagata, Y. A dipole mode in the tropical Indian Ocean. Nature 1999, 401, 360-363. [CrossRef] [PubMed]

49. Ashok, K.; Guan, Z.; Saji, N.H.; Yamagata, T. Individual combined influences of the ENSO and Indian Ocean Dipole on the Indian summer monsoon. J. Clim. 2004, 17, 3141-3155. [CrossRef]

50. Krishnamurthi, V.; Goswami, B.N. Indian Monsoon ENSO relationship on interdecadal timescale. Am. Meteorol. Soc. 2000, 13, 579-595. [CrossRef]

51. Reason, C.J.C.; Allan, R.J.; Lindesay, J.A.; Ansell, T.J. Enso and climatic signals across the Indian Ocean basin in the global context: Part I, Interannual composite patterns. Int. J. Climatol. 2000, 20, 1285-1327. [CrossRef]

52. Allan, R.J.; Reason, C.J.C.; Lindesay, J.A.; Ansell, T.J. Protracted ENSO episodes and their impacts in the Indian Ocean region. Deep Sea Res. 2003, 50, 2331-2347. [CrossRef]

53. Gadgil, S.; Vinaychandran, P.N.; Francis, P.A.; Gadgil, S. Extremes of Indian summer monsoon rainfall, ENSO, equatorial Indian Ocean Oscillation. Geophys. Res. Lett. 2004, 31, L12213. [CrossRef]

54. Klein, S.A.; Soden, B.J.; Lau, N.C. Remote Sea Surface Temperature Variations during ENSO: Evidence for a Tropical Atmospheric Bridge. J. Clim. 1999, 12, 917-932. [CrossRef]

55. Loo, Y.Y.; Billa, L.; Singh, A. Effect of climate change on seasonal monsoon in Asia and its impact on the variability of monsoon rainfall in Southeast Asia. Geosci. Front. 2015, 6, 817-823. [CrossRef]

56. Mazdiyasni, O.; AghaKouchak, A. Substantial increase in concurrent droughts and heatwaves in the United States. Proc. Natl. Acad. Sci. USA 2015, 112, 11484-11489. [CrossRef]

57. Mann, H.B. Nonparametric tests against trend. Econ. J. Econ. Soc. 1945, 13, 245-259. [CrossRef]

58. Kendall, M.G. Rank Correlation Methods; Charles Griffin: London, UK, 1975.

59. Pettitt, A. A non-parametric approach to the change-point problem. Appl. Stat. 1979, 28, 126-135. [CrossRef]

60. Shannon, C.E. A mathematical theory of communication. Bell. Syst. Tech. J. 1948, 27, 379-423. [CrossRef]

61. Geological Survey of India (GSI). Geological Survey of India, MOI, Government of India. 2016. Available online: http:/ / www.portal.gsi.gov.in/ (accessed on 10 March 2016).

62. India Water Portal (IWP). India Water Portal Met Data. 2016. Available online: http:/ / www.indiawaterportal. org/met_data / (accessed on 12 March 2016).

63. National Oceanic and Atmospheric Administration (NOAA). Niño 3.4: Standard PSD Format. 2015. Available online: http:/ / www.esrl.noaa.gov/psd/gcos_wgsp/Timeseries/Nino34/ (accessed on 14 March 2016).

64. Zhang, X.; David Harvey, K.; Hogg, W.D.; Yuzyk, T.R. Trends in Canadian streamflow. Water Resour. Res. 2001, 37, 987-998. [CrossRef]

65. Tamaddun, K.; Kalra, A.; Ahmad, S. Identification of Streamflow Changes across the Continental United States Using Variable Record Lengths. Hydrology 2016, 3, 24. [CrossRef]

66. Mauget, S.A. Multidecadal regime shifts in U.S. streamflow, precipitation, and temperature at the end of the twentieth century. J. Clim. 2003, 16, 3905-3916. [CrossRef]

67. Kalra, A.; Sagarika, S.; Pathak, P.; Ahmad, S. Hydro-climatological changes in the Colorado River Basin over a century. Hydrol. Sci. J. 2017, 62, 2280-2296. [CrossRef]

68. Sagarika, S.; Kalra, A.; Ahmad, S. Evaluating the effect of persistence on long-term trends and analyzing step changes in streamflows of the continental United States. J. Hydrol. 2014, 517, 36-53. [CrossRef]

69. Milly, P.C.D.; Betancourt, J.; Falkenmark, M.; Hirsch, R.M.; Kundzewicz, Z.W.; Lettenmaier, D.P.; Stouffer, R.J. Stationarity is dead: Whither water management? Science 2008, 319, 573-574. [CrossRef]

70. Lins, H.; Slack, J. Streamflow trends in the United States. Geophys. Res. Lett. 1999, 26, 227-230. [CrossRef] 
71. Önöz, B.; Bayazit, M. The power of statistical tests for trend detection. Turk. J. Eng. Environ. Sci. 2003, 27, 247-251.

72. Burn, D.H. Climatic influences on streamflow timing in the headwaters of the Mackenzie River Basin. J. Hydrol. 2008, 352, 225-238. [CrossRef]

73. Villarini, G.; Serinaldi, F.; Smith, J.A.; Krajewski, W.F. On the stationarity of annual flood peaks in the continental United States during the 20th century. Water Resour. Res. 2009, 45. [CrossRef]

74. Kumar, S.; Merwade, V.; Kam, J.; Thurner, K. Streamflow trends in Indiana: Effects of long term persistence, precipitation and subsurface drains. J. Hydrol. 2009, 374, 171-183. [CrossRef]

75. Theil, H. A rank-invariant method of linear and polynomial regression analysis. Adv. Stud. Theor. Appl. Econ. 1950, 23, 345-381.

76. Sen, P.K. Estimates of the regression coefficient based on Kendall's Tau. J. Am. Stat. Assoc. 1968, 63, 1379-1389. [CrossRef]

77. Wilks, D.S. On "Field Significance" and the false discovery rate. J. Appl. Meteorol. Climatol. 2006, 45, 1181-1189. [CrossRef]

78. Mishra, A.K.; Özger, M.; Singh, V.P. An entropy-based investigation into the variability of precipitation. J. Hydrol. 2009, 370, 139-154. [CrossRef]

79. Singh, V.P. The use of entropy in hydrology and water resources. Hydrol. Process. 1997, 11, 587-626. [CrossRef]

80. Sarlis, N.V.; Skordas, E.S.; Varotsos, P.A.; Nagao, T.; Kamogawa, M.; Tanaka, H.; Uyeda, S. Seismicity order parameter fluctuations in Japan. Proc. Natl. Acad. Sci. USA 2013, 110, 13734. [CrossRef]

81. Varotsos, P.A.; Sarlis, N.V.; Skordas, E.S.; Lazaridou, M.S. Seismic Electric Signals: An additional fact showing their physical interconnection with seismicity. Tectonophysics 2013, 589, 116. [CrossRef]

82. Sarlis, N.V.; Skordas, E.S.; Varotsos, P.A.; Ramírez-Rojas, A.; Flores-Márquez, E.L. Natural time analysis: On the deadly Mexico M8.2 earthquake on 7 September 2017. Physica A 2018, 506, 625. [CrossRef]

83. Sarlis, N.V.; Skordas, E.S.; Varotsos, P.A. A remarkable change of the entropy of seismicity in natural time under time reversal before the super-giant M9 Tohoku earthquake on 11 March 2011. Europhys. Lett. 2018, 124, 29001. [CrossRef]

84. Varotsos, C.A.; Tzanis, C.; Cracknell, A.P. Precursory signals of the major El Niño Southern Oscillation events. Theor. Appl. Climatol. 2016, 124, 903. [CrossRef]

85. Varotsos, C.A.; Tzanis, C.G.; Sarlis, N.V. On the progress of the 2015-2016 El Niño event. Atmos. Chem. Phys. 2016, 16, 2007-2011. [CrossRef]

86. Varotsos, C.A.; Sarlis, N.V.; Efstathiou, M. On the association between the recent episode of the quasi-biennial oscillation and the strong El Niño event. Theor. Appl. Climatol. 2018, 133, 569. [CrossRef]

87. Charles, C.D. Interaction between the ENSO and the Asian Monsoon in a Coral Record of Tropical Climate. Science 1997, 69, 27-42. [CrossRef]

88. Singh, R.P.; Roy, S.; Kogan, F. Vegetation and temperature condition indices from NOAA AVHRR data for drought monitoring over India. Int. J. Remote Sens. 2003, 24, 4393-4402. [CrossRef]

89. Kohli, R.K.; Batish, D.R.; Singh, H.P.; Dogra, K.S. Status, invasiveness and environmental threats of three tropical American invasive weeds (Parthenium hysterophorus L., Ageratum conyzoides L., Lantana camara L.) in India. Biol. Invasions 2006, 8, 1501-1510. [CrossRef]

(c) 2019 by the authors. Licensee MDPI, Basel, Switzerland. This article is an open access article distributed under the terms and conditions of the Creative Commons Attribution (CC BY) license (http:// creativecommons.org/licenses/by/4.0/). 